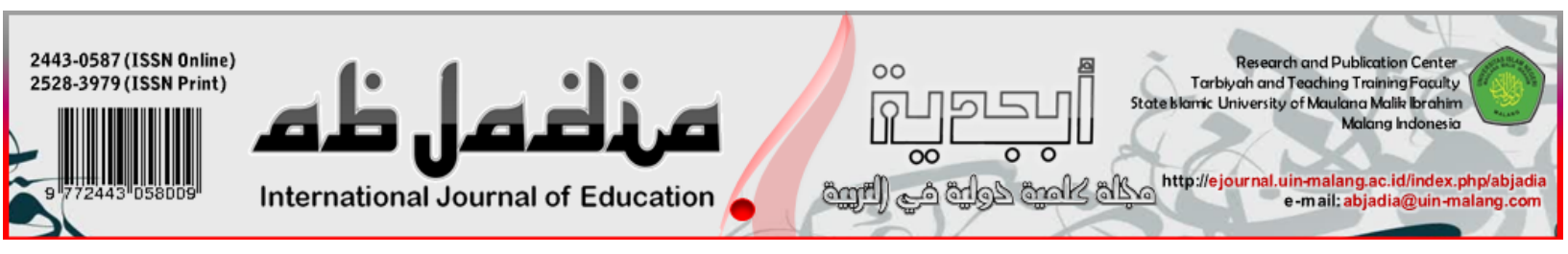

\title{
CULTURE SHOCK EXPERIENCES OF INDONESIAN UNIVERSITY STUDENTS IN TEACHING PRACTICE AND COMMUNITY SERVICE IN THAILAND
}

\author{
Dian Sri Wahyuni \\ Institut Agama Islam Negeri (IAIN) Kediri, Indonesia
}

Article History:

Received : 2019-01-24

Revised : 2019-01-30

Accepted : 2019-11-27

Published : 2019-12-30

\section{Keywords:}

Culture Shock, Strategies, Teaching

Practice, Community Service, Thailand

$\overline{\text { Correspondence Address: }}$

diansw.cse@gmail.com

\begin{abstract}
This study did design to explore culture shock experiences faced by Indonesian university students in doing teaching practice and community service in southern border province Thailand, and to describe the strategies used to deal with cultural differences and problems. There were thirty-eight students of the university from twelve universities in Indonesia who responded to the open-ended questionnaires sent by the writer through google docs link. The data were analyzed using grounded theory code as a basis for the thematic analysis. The findings revealed that there was six culture shock experienced by Indonesian university students, namely: language and communication problems, lifestyle and cultural differences, social support and making friends, positive experiences, academic issues, and psychological issues. The most dominant shock experience faced by Indonesian university students was positive experiences. As for the strategies to deal with cultural differences and problems, there was found four strategies used by Indonesian university students, namely: self-confidence and optimism, accepting the new culture, seeking social support, and language training. The most procedure mentioned by Indonesian university students was taking a new culture.
\end{abstract}

\section{C) Introduction}

Culture shock is defined as the impact of feeling anxiety and strain when facing a new culture. Equally, a person who got religion shock felt, such as confused, suffered, and unable to accustom cultural cues and social rules (Oberg, 1960). Adapting new different cultures could be one of the problems in doing teaching practice and community service. The transition from one culture to another could be a shock when cultural differences can play a significant part in the success of international teaching practice and community service. Besides, it is not easy for people, especially university students, to know well about some other culture. Moreover, they need to get information through direct interaction with a new school and community they have.

This condition could not be avoided since Indonesian students of the university at the 4th year have to take the Community Service on 7th Semester and Teaching Practice Course 8th Semester. Nowadays, teaching practice and community service are not only in public area that is in Indonesia, but it also grows to International such as South 
Thailand. When some of the Indonesian universities have signed Memorandum of Understanding (MoU) with Thailand, many students of these universities become a part of this program. This international program is held by the Abroad Association of Southern Border Provinces of Thailand. Through this program, Indonesian University students faced a new society and any student level of teaching practice and community service in this country. As a result, the differences in cultures then affects the interaction between teacher and students, that is between Indonesian student who did teaching practice-community service and Thailand students.

The implementation of this international teaching practice and community service are precisely in the Southern Border Provinces of Thailand. Those provinces are Pattani, Yala, Narathiwat, and Songkhla. Again, the new areas in 2017 also included Nakhon Si Thammarat and Krabi. It takes about five months to do this program. The Indonesian students will be sent to each school at any level in these provinces. Each university student will be mixed with other difference university students. So that is why they will find a new atmosphere in this cultural change.

Smythe's study (1988) revealed that culture shock experiences could have a beneficial influence on both pedagogy and intercultural understanding. Indeed, Baier (2005) surveyed International Students: Culture Shock and Adaptation to the U.S. Culture. The participants were 45 international (western and non-western) students attending a Michigan community college. The instruments used are the survey questionnaire and interview. The finding of the mixed-method study shows that there is a significant positive correlation was found between cultural adjustment and the experience of culture shock symptoms.

Differently, Poedjiastutie's study (2009) about culture shock experienced by international students studying at Indonesian universities revealed that three points of academic life make international students experience culture shock, namely: teacher s roles and attitudes, poorly organized programs, and the local student's attitudes. In social life, it found that international students experienced culture shock in three aspects, namely: women-men relationships, different ways of thinking, and different habits.

This study designed to explore culture shock experiences faced by Indonesian university students in doing teaching practice and community service in the southern border province of Thailand and to describe the strategies used to deal with cultural differences and problems.

\section{$\mathbb{Q}$ Theoretical Support}

\section{Culture}

There are many definitions of culture. First of all, religion is involving a cognition system that structures people, behavior, or emotions (Goodenough, 1957). It is a pattern that recognizes all of these things. Equally, the culture explained by Strauss (1981) as 
cumulative mind creations of shared symbolic systems. Another approach of religion defines religion as a system that sharing both symbols and meaning (Keesing, 1974). To sum up, culture is systems of cognition, structure, and logo that crucial for humans.

Some educationalists have discussed the importance of culture. As in his book, Clifford Geertz (1973) stated that: "Without human beings, there is no culture, obviously; but likewise, and more significantly, without culture, there are no human beings." Besides, Schwartz \& Bilsky, (1987) who researched culture stated that culture directly affects rules and norm that makes human could guide their daily behaviors in one primary culture orientation. Additionally, an individual communication style, value system, and practices were preferred by culture (Gudykunst, 1996). From the statements above, it can conclude that religion is essential for people's whole way of life because it becomes a part of human beings.

\section{Culture Shock}

Experiences in a new culture may result in culture shock, which is defined by Winkelman (1994) as a disorientated feeling that occurs when people faced with different cultures. It happens especially when individuals have totally faced a new culture, as is usually the case with international students. Culture Shock term existed in the literature since the early 1950s. An anthropologist Kalervo Oberg (1960) explained culture shock as the consequence of strain and anxiety resulting from contact with a new culture and the feelings of loss, confusion, and impotence, which are due to loss of accustomed cultural cues and social rules. The study of a culture shock then developed into contemporary theories, those are 'culture learning' and 'stress and coping' models, and 'social identification' theory (Zhou, 2008). This is also mentioned previously by Phinney (1990) that there are two major conceptual approaches used in social identification, namely: acculturation and social identity theory.

Similarly, culture shock often results in feelings of anxiety and confusion associated with cultural and social rule changes (Wilson, 2011). These definitions seem to be in a cynical explanation. Others, however, it is also defined positive that culture shock as a learning experience that gives the beneficial for the people (Sitton, 1976). Moreover, these could be summarized that culture shock is a disorientated feeling experienced by someone who is suddenly subjected to an unfamiliar culture, way of life, or set of attitudes.

\section{Stages in culture shock}

The experience that has been faced by someone could be categorized into some steps. Kidder (1992) stated that individuals must first recognize five stages of culture shock before the situation can be resolved. Those stages are honeymoon, disorientation, irritability and hostility, adjustment, and integration; the last is biculturality. Those stages were modified then by Winkelman (1994). He stated that adaptation to the local culture is through understanding and accommodation, while it is not necessarily assimilation, but it is necessary to deal with the culture shock. He then described the phases of culture 
shock in four stages. Firstly, the honeymoon or tourist phase. Secondly, the crisis or cultural shock phase. Thirdly, the adjustment, reorientation, and gradual recovery phase. The last is the adaptation, resolution, or acculturation phase.

\section{Strategies to deal with culture shock}

There are many effective ways to deal with culture shock. Besides, each people are not able to use the same procedure to encounter culture shock. Based on Xia's research (2009), there are three approaches to deal with culture shock. Those are self-confidence and optimism, accepting new cultures, and seeking social support.

The first strategy is self-confidence and optimism. In the field of psychology, there is term self-efficacy, which means the conviction or belief of people that they can overcome the obstacles encountered. People with high self-efficacy usually believe that they can perform the task well because they have full confidence that they will succeed (Xia, 2009). Nevertheless, people with low self-efficacy often tend to give up easily and experience more anxiety when facing troubles (Aronson et al., 2005). Therefore, selfconfidence plays a crucial role in decreasing stress and overcoming obstacles (Xia, 2009).

The second strategies are acceptance, which means accepting other cultures' values and behaviors as not good or bad but simply different. Once people can take them, they will be more comfortable and able to minimize psychological stress. Nevertheless, it is not an easy method. Therefore, interest, curiosity, and willingness are essential. Then reluctant acceptance will cause more psychological discomfort (Phillips, 2003). Also, they are attempting to respect local customs and traditions may also be a relatively easy way of accepting new cultures.

The last strategy is seeking social support. It regarded as an effective way during the anti-stress process based on Xia's research (2009). In this strategy, people receive consolation, caring, encouragement, advice, approval, and help from others around them. It seems that people who have friends to lean and deal with stress better. When social support decreases, common psychological problems such as depression, anxiety, and feeling of helplessness increase. For instance, when people encounter many difficulties, such as culture shock, their friends may help them analyze the reason and give them several suggestions about how to do better in the future.

\section{Integrated Teaching Practice and Community Service}

Integrated teaching practice and community service is a subject of the study which combined teaching practice and community service ("Petunjuk Teknis Pelakanaan Kuliah Kerja Nyata (KKN) Praktek Pengalaman Lapangan (PPL) Angkatan VIII di Thailand," 2017). Teaching practice could be described as a period when students are working to apply theory in practice (Kiggundu \& Nayimuli, 2009). Indeed, teaching practice can be conducted in several forms depending on the institutions (Perry, 2018). While, community service, in other named student study service, is a link of academic study concept combined with community service practical experience (Krisnawati, 2009). 
In conclusion, integrated teaching practice and community service is the integration of teaching practice and community service; those are in management and time aspects.

The purpose of integrated teaching practice and community service program explained in "Petunjuk Teknis Pelakanaan Kuliah Kerja Nyata (KKN) Praktek Pengalaman Lapangan (PPL) Angkatan VIII di Thailand" (2017) is to develop the students' competition as professional teachers. This also could give valuable experience to students of the university, especially the fourth year students in teaching-learning at the schools. Indeed, it also gives students of university practice and develops their profession in their fields of study. Moreover, the students could apply their knowledge and teaching skills that they have in real life in formal schools, in this case, is in the Southern Border Province of Thailand.

\section{Southern Border Province Thailand}

Thailand could be divided into four different regions based on its land features. They are the northern region, the Khorat Plateau, the central region, and the southern region (Phillips, 2007). The physical traits of southern border province Thailand explained follow:

\section{The physical landscape of southern border province Thailand}

Based on the topography defined by Phillips (2007, p. 16), the southern region of Thailand divided into Southern Thailand East Coast and Southern Thailand West Coast. There are ten provinces from north to south, which are Phetchaburi, Prachuap Khiri Khan, Chumphon, Surat Thani, Nakhon Si Thammarat, Phatthalung, Songkhla, Pattani, Yala, and Narathiwat belong to Southern Thailand East Coast. While there are six provinces, those are Ranong, Phang Nga, Krabi, Phuket, Trang and Satun in Southern Thailand West Coast.

\section{Characteristic and personality of the people}

Thai people are quite homogeneous. Ethnically, 75 percent being of Thai heritage, 14 percent being of Chinese heritage, and some 35 different ethnic groups making up the other 11 percent of the population. Thainess is a term that is thrown in Thailand a lot to describe the Thai people. Thai people have been described as easy-going, friendly, selfconfident, complacent, polite, laid back, discreet, modest, cheerful, neat, clean, respectful, grateful, obedient, loyal, and differential (Phillips, 2007, p. 41).

\section{Religion}

More than 94 percent of Thai people were Buddhist. Compared to Buddhism, all other faiths in Thailand are relatively minor. Islam and Christianity both exist in the country. Muslims live primarily in the south and Bangkok. They make up 4.6 percent of the population, while Christians number less than 1 percent of the population (Phillips, 2007, p. 43).

\section{Thai Language}


Still in the same literature, Thai is part of the Sino-Tibetan language family, but it has been influenced over time by other languages. The language has 44 consonants and 18 vowels. Tone marks are used in written communication to show how words are to spoken. Each different tone creates different meanings in the Thai Language. Other languages used in Thai are Malay and English.

\section{Life style}

Thai people's daily life could be drawn to their lifestyle, as explained by Phillips (2007, p. 48). The range of spices goes from hot and spicy to mellow and delicate. Spices and ingredients used in cooking include hot peppers, lime juice, lemongrass, ground peanut, and black pepper. While ginger, coconut milk, coriander, garlic, sweet basil, mint, tomatoes, onion, and curry are also widely used. Unusually, ingredients like crickets and various insect larvae are eaten in Thailand.

\section{[Q] Method}

Since this research conducted to explore and create the new theory about culture shock experiences faced by Indonesian students of university during their teaching practice and community service in Southern Border Province Thailand on $8^{\text {th }}$ Generation, this research employed grounded theory design (Glaser and Strauss, 1967). The subjects of this study were 38 students of university from 12 universities in Indonesia, namely: Muhammadiyah University of Tangerang, Serambi Mekkah University of Banda Aceh, Muslim University of Bireun Aceh, State Islamic Institute of Tulungagung, State College for Islamic Studies Kediri, State Islamic Institute of Jember, Islamic Institute of Ibrahim Genteng, Islamic Institute of Darussalam Blokagung, Hasyim Asy'ari University of Jombang, Muhammadiyah University of Jember, Muhammadiyah University of Sidoarjo, and State Islamic University of Sunan Ampel Surabaya.

The open-ended questionnaire was developed to get the data of this study. Name, university, major, subject of the study, and teaching practice and community service place are required. The instrument used in this research is in Bahasa Indonesia (see Appendix). The researcher translated it from English to Indonesian because the participants are from different majors and different departments. The survey questionnaire consisted of 10 questions. The researcher was selected and adapted for the current study from interview questions of existing literature (Rajapaksa and Dundes, 2002), and the previous research done by Baier (2005). The last question introduced the Indonesian university students to Xia's (2009) strategies to deal with culture shock based on their primary personal approach used. The data collected from three steps. Firstly, the researcher created an online google docs account, inputs, and sets the questionnaires. Secondly, all of the participants asked to fill the questionnaire voluntarily through the link of google docs. Thirdly, the researcher took the data in google docs then analyze it.

The data were analyzed using grounded theory code as a basis for the thematic analysis. The following themes emerged for thematic analysis of culture shock 
experiences:

1. A theme I: Language and Communication Problems

2. Theme II: Life Style and Cultural Differences

3. Theme III: Social Support and Making Friends

4. Theme IV: Positive Experiences

5. Theme V: Academic Problems

6. Theme VI: Psychological Problems

Besides, the following codes emerged for analysis of strategies to deal with culture shock:

1. ScO: Self-confidence and Optimism

2. ANW: Accepting New Culture

3. S3: Seeking Social Support

4. LT: Language Training

The researcher divided the activity in analyzing data into three activities. They were translating, coding, and presenting the data results. Firstly, the open-ended survey questionnaire was translated from Indonesian to English without adding or reducing the context answer given. After the researcher got the data that have translated, the researcher started to code the data using thematic analysis. The last process was presenting data results based on the themes of culture shock experiences found. The data was presented originally in context as the subjects answer on the questionnaire given. Whether the subjects' answers are various or not, the data presented as it was.

\section{Result}

In this research, the researcher finds out culture shock experiences and the strategies to deal with cultural differences and problems. The data presented as follows:

\section{Culture shock experiences of Indonesian university students}

This study finds out some culture shock experiences faced by Indonesian university students in doing teaching practice and community service in the southern border province of Thailand. Those explained in Table 1.

Table 1. Culture Shock Experiences of Indonesian University Students

\begin{tabular}{|l|l|c|c|}
\hline No & \multicolumn{1}{|c|}{ Culture Shock Experiences } & Subjects Total & Percentage \\
\hline 1. & Language and Communication Problems & 13 & $34 \%$ \\
\hline 2. & LifeStyle and Cultural Differences & 16 & $42 \%$ \\
\hline 3. & Social Support and Making Friends & 12 & $32 \%$ \\
\hline 4. & Positive Experiences & 38 & $100 \%$ \\
\hline 5. & Academic Problems & 20 & $53 \%$ \\
\hline 6. & Psychological Problems & 8 & $21 \%$ \\
\hline
\end{tabular}

\section{Language and Communication Problems}

The first culture shock experience is language and communication problems. Thirteen people mentioned language and communication problems as one of the most 
difficult experiences in the surveys. Eight sub-themes are explaining this problem. They are 'experiencing common language problem,' 'students were speaking in Thai fully,' 'having difficulties in understanding the language,' 'having language difference,' 'feeling frustrated with language,' 'having difficulties in doing communication,' 'could not communicate,' and 'misunderstanding.'

When exploring this experience, six Indonesian university students mentioned that they do not understand the language, the language is very different, and difficult to study the language. An Indonesian university student from Hasyim Asy'ari University of Jombang became frustrated because of the word:

"...in the first month. I felt frustrated with the language because I lived in a place where almost all of the society could speak in Malay; in contrast, the minority people could speak in English then their pronunciation was difficult to gues also when they talked using their language (Thai language), I felt confused because I did not know what they talked are."

Another crucial problem is in case of communication with Thai people. Five Indonesian university students said that they were challenging to do contact, could not do discussion, and got misunderstanding experience. Some examples from the openended questions answer about the difficulty in communication included: "I could not communicate with the society because of the problem in Language," "I felt upset only when doing communication, ...people did not know well Malay and English Language." One participant from the State Islamic Institute of Tulungagung described her experience with communicating: "I felt depressed when I taught playground (anuban) because, in the first meeting, the language was my first crucial problem to communicate with kids who were still 3-6 years old." Furthermore, another Indonesian university student often had a misunderstanding experience.

\section{LifeStyle and Cultural Differences}

The second culture shock experience is a lifestyle and cultural differences. 16 Indonesian university students mentioned these differences as one of culture shock experiences. Six sub-themes are explaining this problem. They are 'having different the way to celebrate great Islamic day,' 'having different habitual activities,' 'experiencing difficulties in transportation,' 'having the different way to give punishment,' 'having different living environment (the condition of this province),' and 'having different kind of food.'

When celebrating a great Islamic day, Thai people are different from the Indonesian people. An Indonesian university student from State Islamic Institute of Tulungagung explained, "I felt worst loneliness when Ied Fitri, where it was fully different from Indonesia culture, for example, there were no takbir for 24 hours nonstop, firecracker, and there was no traditional food in that great Islamic day."

Some Indonesian university students mentioned, there were also some differences between Indonesian and Thai habitual activities. Two Indonesian university students explained this difference. A university student from the State Islamic University of Surabaya 
mentioned that he spent most of his time at home on the weekend. He did the lazy activity that was sleeping for a day full. Indeed, he also explained, "Here Thai male children like to say bad words besides many of them like the same gender."

In the transportation problem, a university student from the Muhammadiyah University of Jember explained that there were no transportations that could use to go everywhere. Especially on holiday, he could not have a vocation because of the transportation limit. The school where he did teaching practice and community service did not give him a vehicle. So that's why he could not reach the places he wanted quickly.

Then, the way to give punishment in Thailand also becomes one of culture shock experiences. An Indonesian university student from State Islamic University of Sunan Ampel Surabaya explained whipped the students using rattan is usual in Thailand. She then told more, "...In my opinion, that punishment is too extreme because I never found it in Indonesia."

Another lifestyle and cultural differences experienced by university students was the different living environment. An Indonesian university student from the Muhammadiyah University of Tangerang said, "Yes, I've ever felt depressed. It could be because I was not accustomed to Thailand's environment." An Indonesian university student from the State Islamic Institute of Jember explained, "the first time I was in Thailand, I felt worried. Because I was in a place that was far from my home, and I never came here before and would be here for a long time. Indeed, the condition of this province that always guided by the army every time."

Furthermore, some university students mentioned that it was somewhat difficult for them to adjust to the food. A university student from Muhammadiyah University of Jember explained:

"...first, I was given Krabu rice (one of Thailand cuisine), the color is blue, and the vegetables are uncooked. Indeed, there is also Thailand vegetable leaf that is Budu, I could not eat it because of not delicious and putrid, and my tongue still could not accept Thailand food. Second, Thailand's cuisine is hot and sour made. I have got stomachache because that is not ordinary for me. Third, Laksa, Thailand cuisine made from noodles that were boiled, served with fish gravy that tasted bad with uncooked terasi, and any kinds of uncooked leaves made me shocked, I could not eat that food. I prefer to eat cooked rice with a fried egg."

\section{Social Support and Making Friends}

The third culture shock experience is social support and making friends. Answering the questionnaire about this, 12 Indonesian university students also mentioned this problem as one of their culture shock experiences. Five sub-themes are indicating this problem. Those are 'having a different opinion,' 'having individualist personality,' 'having limited Indonesian and Thai friends,' 'having own business', and 'feeling isolated.'

An Indonesian university student from State College for Islamic Studies Kediri mentioned that she has a different opinion with her roommate, who is an Indonesian friend. She said, "I lived with my roommate, who was different from my ethic. So, my communication with my society was not good in several early weeks, arrived in Thailand." 
The other two university students mentioned that Thai people are an individualist. A university student, who is still the same university as before said, "Most of them (Thai people) was an individualist." Another university student from Muhammadiyah University of Jember explained more this statement with, "...because some people behavior were not care, so that's why I did not know with whom I had to give questions, told my stories and asked the solution."

Another sub-theme found in this theme is having limited Indonesian and Thai friends. Two Indonesian university students experienced this problem. An Indonesian university student from Muhammadiyah University of Jember had limited Indonesian friends; this participant then explained it with, "...it was the first time when I arrived in my teaching practice place because there were no Indonesian friends." Differently, an Indonesian university student from the same university had experience in having limited both Indonesian and Thai friends, this participant explained, "when Ramadhan, holiday time, and the dormitory students went home to their houses. At that time, I felt lonely, and I only lived with my roommate. So, I would like to go home at that time."

The next problem found in this theme is business. An Indonesian university student from State College for Islamic Studies of Kediri stated that teachers in her school were very busy. They always did their works. Furthermore, they did not care with her because they were so busy with those works.

Then, in feeling isolated, six Indonesian university students stated that they experienced this problem. An Indonesian university student from State Islamic University of Sunan Ampel Surabaya explained, "...during the first month is the worst time for me, where language, different culture, I felt isolated." Other different two Indonesian university students from State Islamic University of Sunan Ampel Surabaya and the Hasyim Asy'ary University of Jombang experienced this case because there were no people who could talk with them. So, they felt isolated because they did not do communication with people there.

\section{Positive Experiences}

The fourth culture shock experience is positive experiences. In spite of the difficulties mentioned in themes before, all of the Indonesian university students also experienced excellent skills. Those are experienced in these three sub-themes, namely: 'become like Thai family members,' 'doing teaching,' and 'participating consulate program.'

One of the positive experiences is when they become like Thai family members. 20 Indonesian university students mentioned this sub-theme as their experiences. An Indonesian university student from Serambi Mekkah University of Banda Aceh said, "I got new friends, new family, and new experience." Indeed, an Indonesian university student from State Islamic University of Sunan Ampel Surabaya explained, "...different language, but we always keep love with the school and boarding house."

Furthermore, an Indonesian university student from Muhammadiyah University of Sidoarjo explained, "The positive experience that I still remember is love between Indonesian and Thai Moslems..." 
Indeed, talking about teaching, 15 Indonesian university students experienced this moment. Here are examples of some answers. An Indonesian university student from State College for Islamic Studies Kediri said, "...I could bring my students to be the champion (Indonesian Nasyid, Indonesian Poetry, and English speakers)." Then, an Indonesian university student from the Muhammadiyah University of Jember also explained the experience of teaching Thai students and guiding them to become the first winner in the Center of Languages and ASEAN Studies (CLAS).

Also, some of the Indonesian university students had experience when they participated in the consulate program. Three participants experienced it at this moment. An Indonesian university student from Muhammadiyah University of Sidoarjo explained, "I could meet the best people there." The words the best people here means that Indonesian consulate people. Other, an Indonesian university student from Muhammadiyah University of Tangerang explained that he got the best experience when "Experienced being a leader August $17^{\text {th }}$ in Indonesian consulate at that time." Indeed, an Indonesian university student from the Muslim University of Bireun Aceh explained, "The society was warmful, and participating with consulate (with Indonesian people)..."

\section{Academic Problems}

The fifth culture shock experience is academic problems. 22 Indonesian university students mentioned these differences as one of culture shock experiences. Four sub-themes are explaining this problem. They are 'teaching the different subject,' 'the students could not catch the material,' 'feeling tired with the school assignments, and 'teaching in full-day school.'

The first sub-theme mentioned in academic problems is taught in different subjects. An example from a survey answer from an Indonesian university student from the State Islamic Institute of Tulungagung said, "...I was asked to teach differently with my field of study." The second sub-theme is the students could not catch the material. An example from a survey answer from an Indonesian university student from the Muhammadiyah University of Jember explained, "...I felt depressed when I had to be ready to teach every condition and situation. I felt frustrated when my students could not catch the material I taught well in the first week." The third sub-theme is felt tired with the school assignments. An example from a survey answer from an Indonesian university student from the Muhammadiyah University of Tangerang said, "...because of many assignments and deadlines. They made me tired so that I had to stay up all the nights, then made me need more time to sleep." The last sub-theme is about a full-day school. An example from a survey answer from an Indonesian university student from Muhammadiyah University of Jember explained, "...teaching full-day school and extracurricular made my power empty, and it made me need more sleeping time."

\section{Psychological Problems}

The sixth culture shock experience is mental problems. 8 Indonesian university students also mentioned this problem as one of their culture shock experiences. Three subthemes are indicating this problem. Those are 'feeling sad and missed,' 'feeling frustrated,' and 'first time going aboard.' 
The first sub-theme mentioned in psychological problems is that six Indonesian university students felt sad and missed their home. An example from a survey answer from an Indonesian university student from the Islamic Institute of Darussalam Blokagung said, "...when the first time, I remembered my family, then I missed them." And, an Indonesian university student from Muslim university of Bireun Aceh mentioned, "The first time I went there, I felt sad because I was far from my family, but it was not long." Other, second sub-theme mentioned in psychological problems is frustrated. An Indonesian university student from State Islamic Institute of Jember explained, "I've ever got frustrated when Ied Fitri day. Where this moment must be a special moment to join with all of the family." The last sub-theme mentioned in this problem is the first time go aboard. Here, An Indonesian university student from Muhammadiyah University of Jember said, "...because, that was my first time go aboard."

\section{The strategies used by Indonesian university students to deal with cultural differences and problems}

This study also found some strategies used by Indonesian university students to deal with culture shock. The totals of Indonesian university student strategies used are explained in Table 10.

Table 10. Strategies Used to Deal with Cultural Differences and Problems

\begin{tabular}{|c|l|c|c|}
\hline No. & \multicolumn{1}{|c|}{ Strategies } & Subjects Total & Percentage \\
\hline 1. & Self-confidence and optimism & 6 & $16 \%$ \\
\hline 2. & Accepting new culture & 32 & $84 \%$ \\
\hline 3. & Seeking social support & 3 & $8 \%$ \\
\hline 4. & Language Training & 5 & $13 \%$ \\
\hline
\end{tabular}

\section{Self-confidence and optimism}

The first strategy used by Indonesian university students is self-confidence and optimism. 6 Indonesian university students mentioned this strategy as one of their ways to deal with culture shock. There are four examples of strategies indicating this problem. Those are 'believe to our self,' 'remembering our first intention,' 'embracing Pancasila,' 'eating much,' and 'starting it from our self.'

An Indonesian university student from State College for Islamic Studies Kediri mentioned that we have to believe in our self. Believes, in this case, is that the differences will bring out the beauty. Then, an Indonesian university student from the same college said that she always remembers that my first intention of going to Thailand is to make my parents, country, and religion proud of her. Another Indonesian university student from the State Islamic Institute of Tulungagung explained that "Remember the first goal come to Thailand is to serve."

Differently, an Indonesian university student from the Islamic Institute of Ibrahimy Genteng said that embracing Pancasila value is one of the effective ways that is because Pancasila is the official philosophical foundation of the Indonesian state. It means that Pancasila is our way of life. Indeed, an Indonesian university student from the Hasyim Asy'ari University of Jombang explained that she did everything that could build her optimism; it was proven by her explanation, "Eating chocolate and any Thai sausage... All of 
Thai cuisines..." Furthermore, an Indonesian university student from State Islamic University of Sunan Ampel Surabaya explained deeply,

"We have to start it from our self because we have our ability to solve that problem. We could start it from repairing our first intention, our way of thinking, our heart, and our thought. I will take those ways first to deal with that shock problem. Example: if the problem is about communication, I will try to communicate with them."

\section{Accepting new culture}

The second strategy used by Indonesian university students is taking a new culture. Indonesian university students mentioned this strategy as the most effective way to deal with culture shock. There are five examples of strategies indicating this problem. Those are 'studying the Thai language,' 'adapting and socializing,' 'building tolerance and respecting,' 'accepting and understanding,' and 'adjusting.'

An Indonesian university student from State College for Islamic Studies Kediri mentioned that we have to build ourselves by studying the Thai language. Then an Indonesian university student from the same college but a different subject said the same argument; deeply, she explored the reason why we have to study their language. That is because when we could master their language, we will be able to interact with them in a good way.

Other ways found in accepting a new culture is adapting and socializing - this strategy purposed by some Indonesian university students. An Indonesian university student from the State Islamic Institute of Tulungagung stated that she joins with organizations and follows many events to deal with cultural problems. It explained more by an Indonesian university student from Muhammadiyah University of Jember explained, "The solution is we have to socialize actively through giving a nice smile and be active with a citizen so that we will not find culture shock." It is in line with an Indonesian university student from Hasyim Asy'ary university of Jombang who said, "We have to open with their culture, exchange our ideas could help us to accept them."

Then, building tolerance and respecting is one of the ways of accepting a new culture. Indonesian university students from the Muhammadiyah University of Tangerang explored, "Through improving our value intolerance with the religion and culture. Then, adapt to the new environment and new culture." Similarly, an Indonesian university student from Serambi Mekkah University of Banda Aceh explored this strategy by saying, "Culture is the identity of the nation, the solution to deal with cultural differences is we have to respect one culture with other cultures."

The next example in this strategy is accepting and understanding. This way proposed by some Indonesian university students. An Indonesian university student from the Muhammadiyah University of Tangerang who explained that we could take a new culture by trying to understand the culture and slowly follow how their culture model is. Then, an Indonesian university student from Serambi Mekkah University of Banda Aceh explained more her acceptance, "I want Thai culture mainly in Songkhla Thailand would be conserved so that Thai culture will not be lost." 
The last, adjusting is the way we get after accepting other cultures. It explained more by some Indonesian university students. An Indonesian university student from the Muslim University of Bireun Aceh told many Thailand culture is almost the same as Indonesian culture, mainly in Aceh. This statement could be indicated as an adjustment. That is because some Thai and Indonesian cultures were accepted then adjusted. Another, an Indonesian university student from the Muhammadiyah University of Sidoarjo said that we have to search the positive sides of the culture so that we could accept the culture.

\section{Seeking social support}

The third strategy used by Indonesian university students is seeking social help. Indonesian university students mentioned this strategy as one of the ways to deal with culture shock. There are two examples of strategies indicating this problem. Those are 'doing discussion and communication,' and 'calling Indonesian friend.'

When we said about seeking social support, the word discussion and communication are one of the ways to find this support. An Indonesian university student from the Islamic Institute of Tulungagung said that we have to make small discussions with the society between us. She said, "...small discussion with the nearest environment." Similarly, another Indonesian university student from State College for Islamic Studies purposed that we have to communicate with the society as many as possible.

Then, calling an Indonesian friend was purposed to reach the strategy of seeking social support. An Indonesian university student from the Muhammadiyah University of Tangerang explained when he experienced culture shock; he then calls some of his friends. He said, "I called my friends through phone..." They are his teaching practice and community service in southern border province Thailand friend.

\section{Language Training}

When exploring the strategies of Indonesian university students dealing with cultural differences and problems, five Indonesian university students also mentioned language training. Two of them are from State College for Islamic Studies Kediri, two of them are from Hasyim Asy'ary university of Jombang, and one of them is from Muhammadiyah University of Tangerang. Talking about this strategy, all those university students agreed that language training is one of the effective strategies. While one university student from Hasyim Asy'ary university of Jombang explored more, "...the training must do first before entering a new culture, in this case, Thailand culture.".

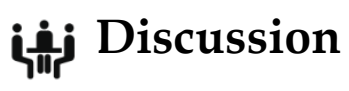

The researcher then discusses culture shock experiences of Indonesian university students and the strategies to deal with cultural differences and problems. They are considered as follow: 


\section{Culture shock experiences of Indonesian university students}

Based on the finding of this study, there are six culture shock experiences. Those are language and communication problems, lifestyle and cultural differences, social support and making friends, positive experiences, academic issues, and psychological problems. It is different from the previous research done by Baier (2005), who has found five culture shock experiences. Those are language and communication problems, lifestyle and cultural differences, social support and making friends, positive skills, and difficult times and experiences. What makes this current study differs from the previous study is because of the various physical traits (physical landscape, characteristic and personality of the people, religion, language, and lifestyle) between the U.S. and South Thailand. Besides, the subjects of the study in the previous research are International students from western countries and non-western countries. While in this current study, the items are Indonesian university students from 12 universities in Indonesia.

The first is language and communication problems. Those problems happened because the Thai language has 44 consonants and 18 vowels. Tone marks are used in the written language to show how words are to be spoken (Phillips, 2007, p. 43). Similar to the previous study done by Baier (2005), language and communication problems in the last survey experienced because language needs to be understood in the context of culture.

The second is a lifestyle and cultural differences. Here, many Indonesian university students experienced in Thai cuisine that is different than Indonesian cuisine. Thailand cuisine is identic with spicy food. The range of spices goes from hot and spicy to mellow and delicate (Phillips, 2007). Indeed, based on the researcher's experience, the eating amount of Thai people are higher than Indonesian. They like eating so much. Besides, their custom food ingredients were also different from ingredients used for cooking Indonesian food. Spices and components used in cooking include hot peppers, lime juice, lemongrass, ground peanut, and black pepper (p. 48).

The third is social support and making friends. For Indonesian university students, doing International teaching practice and community service in Thailand gives the implication that they have to leave their friends and, in most cases, their parents or families. The lack of a social support network could be a challenging experience, especially when students are rather shy and embarrassed to approach people because of their limited confidence or target language knowledge. Besides, that is also because Thai people are quite homogeneous (Phillips, 2007, p. 41). They have some different personalities, such as individualist and friendly. But, in some literature, almost Thai people have been described as easy-going, friendly, self-confident, complacent, polite, laid back, discreet, modest, cheerful, neat, clean, respectful, grateful, obedient, loyal and differential (Hays, 2014). This is different from finding in this study which almost found that Thai people were busy with their works, do not care with Indonesian people, and 
individualist. Also, "cultural differences may be a barrier for making friends" (Baier, 2005, p. 78).

The forth is positive experiences. Besides the negative experience of culture shocks mentioned above, there are some positive experiences faced by Indonesian university students. Based on the findings, there were many positive experiences, such as become like Thai family members, doing teaching and participating in consulate programs. Similar to the result of this study, Baier (2005) also mentioned positive experience in his research. The lessons are different from this study but still somewhat the same. Those are positive college experiences, meeting new people and different cultures, also opportunities.

The fifth is academic problems. Based on this finding, the sub-themes are teaching different subjects; the students could not catch the material, felt tired with the school assignments, and full-day school. It is similar to Poedjiastutie's research that found academic shock as one of the experiences in culture shocks. The difference is in subthemes. In this previous research done by Poedjiastutie (2009), the educational problems faced by international students fell into three categories, namely: teacher's role and attitude, poorly organized program, and local students' perspective.

The sixth culture shock experience faced by Indonesian university students in doing teaching practice and community service in the southern border province of Thailand is psychological shocks. Based on the finding of this study, the sub-themes are feeling sad and missed the Indonesian atmosphere, frustrated, and experiencing the first time go aboard. Those experiences not mentioned in Baier's study (2005). But feeling such as sad missed and frustrated are similar to Oberg's theory of culture shock that w defined as disorientated feeling (Winkelman, 1994).

\section{The strategies used by Indonesian university students to deal with cultural differences and problems}

To deal with culture shock, this research has found all three plans that are purposed by Indonesian university students in doing teaching practice and community service in the southern border province of Thailand. Firstly is self-confidence and optimism. Secondly, it is accepting a new culture. Thirdly is seeking social support. The last is language training. Different from the previous study done by Xia (2009) about the analysis of the impact of culture shock in individual psychology, the last strategy that is language training did not mention in Xia's study. She only found the first three strategies similar to this finding.

The first strategy used by Indonesian university students is self-confidence and optimism. According to this research, we have to believe in our self so that we could be confidence. It is similar to Aronson's statement (2005) that is self-confidence plays a crucial role in decreasing anxiety and overcoming obstacles. Indeed, one of the other ways to get optimism mentioned in this study is by remembering our first intention that is to serve as a teacher and community. Also, embracing Pancasila and eating much also 
mentioned in the finding that could be critical factors to reach self-confidence and optimism. Furthermore, we have to start it from our self.

The second strategy used by Indonesian university students is accepting a new culture. Based on the result, studying the Thai language could be one way indicating that people take a new culture. Then, adapt and socialize with Thai people also could we do. Indeed, building tolerance and respecting, accepting and understanding, also adjusting Thai culture are other ways indicating that we accept Thai culture. It is similar to Phillips (2003), who explored that reluctant acceptance will cause more psychological discomfort. So, attempting to respect local customs and traditions may also be a relatively easy way of accepting new culture.

The third strategy used by Indonesian university students is seeking social support. Based on the finding in this research, one of the ways to apply this strategy is through doing discussion and communication with Thai people. Another way is calling an Indonesian friend. Both of them could build our social support. It is similar to Xia's research (2009), who explained that in seeking social support, people would receive consolation, caring, encouragement, advice, approval, and help from others around them. Indeed, discussion and communication are ways to seek social support from the Thai people. Differently, video or audio calls are ways to find social support from Indonesian people.

The last strategy used by Indonesian university students is language training. All of the participants who have the same statement about practice said that language training is the best training before entering a new country. That is because, as we know that the Thai language is difficult to study. This language has many patterns, one of them is about tone marks (Phillips, 2007). Based on personal researcher experiences who be one of the same teaching practice and community service university students, there were about five tone marks in the Thai language. So that when we said a word using the Thai language in different tone marks, they would have different five possible meanings. It is different from the Indonesian language that there is no tone marks rule. Furthermore, training must do first before entering a new culture, in this case, Thailand's culture.

\section{Conclusion}

Based on the finding and discussion, there are six culture shock experiences faced by Indonesian university students in doing teaching practice and community service in the southern border province of Thailand. Those were language and communication problems, lifestyle and cultural differences, social support and making friends, positive experiences, academic issues, and psychological issues. The most dominant shock experience faced by Indonesian university students was positive experiences. This current research finding is different from the previous research finding because of the various physical traits between the U.S. and South Thailand, also different subjects of the study. As for the strategies to deal with cultural differences and problems, there were 
four strategies used by Indonesian university students. Those were self-confidence and optimism, accepting the new culture, seeking social support, and language training. The most plan mentioned by Indonesian university students was taking a new culture.

\section{Eibliography}

Abroad Alumni Association of Southern Border Province. Petunjuk teknis pelakanaan kuliah kerja nyata (KKN) praktek pengalaman lapangan (PPL) angkatan VIII di Thailand tahun 2017. Thailand: Author.

Aronson. Et al., (2005). Social Psychology (5th ed.). New Jersey: Pearson Education.

Baier, S., T. (2005). International students: culture shock and adaptation to the U.S. culture (Thesis). Eastern Michigan University, Ypsilanti, Michigan.

Cohen, L., Manion, L., \& Marisson, K. (2000). Research method in educational. (London: Routledge).

Creswell, J., W. (2009). Research design: qualitative, quantitative, and mixed-method approaches (3rd ed.). United States of America: Sage Publications.

Geertz, C. (1973). The interpretation of cultures. New York, NY: Basic Books.

Glaser, B. G., \& Strauss, A. L. (1967). The discovery of grounded theory: Strategies for qualitative research. Chicago: Aldine Publishing.

Goodenough, W., H. (1957). Cultural anthropology and linguistics. In a report of the seventh annual round table meeting on linguistics and language study, Ed. P. Garvin. Washington, DC: Georgetown University.

Gudykunst, W. B., Matsumoto, Y., Ting-Toomey, S., Nishida, T., Kim, K., \& Heyman, S. (1996). The influence of cultural individualism-collectivism, self-construals, and individual values on communication styles across cultures. Human Communication Research, 22, 510-543.

Guion, L. A., Diehl, D.C, \& McDonald, D. (2011). Triangulation: Establishing the validity of qualitative studies. (Florida: University of Florida).

Hays, J. (2014). Thai Character and Personality: Sanuk, Thai-Ness, Kreng Jai, Jai Yen, And Social Smoothing. Retrieved May 07, 2018, from http://factsanddetails.com/southeastasia/Thailand/sub5_8c/entry-3219.html.

Keesing, R., M. (1974). Theories of culture. Annual Review of Anthropology, 3, 73-97.

Kidder, L., H. (1992). Requirements for being Japanese: stories of returnees. International Journal of Intercultural Relations, 16, 384.

Kiggundu, E. \& Nayimuli, S. (2009). Teaching practice: a make or break phase for student teachers. South African Journal of Education. 29,345-358.

Krisnawati, L., D. (2009). Service-learning in Christian university: past, present, and future states. New Horizons in Education. 57 (3), 74-81.

Oberg, K. (1960). Cultural shock: Adjustment to new cultural environments. Practical Anthropology, 4, 177-182. 
Perry, R. (2004). Teaching practice for early childhood. A guide for students. Retrieved May 07, 2018, from http:/ / www Routledge.com catalogues./0418114838.pdf.

Phillips, D., A. (2007). Modern world Nations, Thailand. New York: NY, Chelsea House.

Phillips, J. (2003). In the know in Japan: the indispensable guide to working and living in Japan. Westminster: Random Information Group.

Phinney, J., S. (1990). Ethnic identity in adolescents and adults: Review of research. Psychological Bulletin, 108, 499-514.

Poedjiastutie, D. (2009). Culture shock experienced by foreign students studying at Indonesian universities. TEFLIN Journal, 20 (1), 25-36.

Rajapaksa, S., \& Dundes, L. (2002). It's a long way home: International student

adjustment to living in the United States. College Student Retention, 4 (1), 15-28.

Schwartz, S., \& Bilsky W. (1987). Toward a psychological structure of human values. Journal of Personality and Social Psychology, 53, 550-562.

Sitton, T. (1976). The pedagogy of culture shock. The Social Studies, 67 (5), 206-212.

Smythe, J., L. (2012). Culture shocked: The intercultural experiences and insights of returned peace corps volunteer educators (Doctoral dissertation). Faculty of the Graduate College of the Oklahoma State University, Stillwater, OK.

Strauss, L. C. (1971). Mythologiques, IV: L'homme nu. Paris: Plon. (English Translation: The naked man. New York: Harper and Row, 1981).

Wilson, G., P. (2011). Fitting-in: Sociocultural adaptation of international graduate students. NERA Conference Proceedings, 21.

Winkelman, M., J. (1994). Cultural shock and adaptation. Journal of Counseling and Development, 73, 121-126.

Xia, J. (2009) Analysis of impact of culture shock in individual psychology. International Journal of Psychology Studies, 1 (2), 99-101.

Zhou, Y., Jindal-Snape, D., Topping, K., \& Todman, J. (2008) Theoretical models of culture shock and adaptation in international students in higher education. Studies in Higher Education, 33, 63-75.

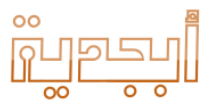

